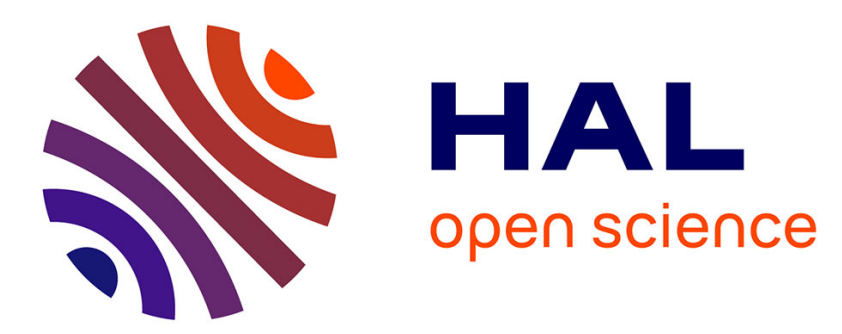

\title{
Professionals' endorsement of behavioral finance: Does it impact their perception of markets and themselves?
}

Lukas Menkhoff, Marina Nikiforow

\section{To cite this version:}

Lukas Menkhoff, Marina Nikiforow. Professionals' endorsement of behavioral finance: Does it impact their perception of markets and themselves?. Journal of Economic Behavior and Organization, 2009, 71 (2), pp.318. 10.1016/j.jebo.2009.04.004 . hal-00690277

\section{HAL Id: hal-00690277 https://hal.science/hal-00690277}

Submitted on 23 Apr 2012

HAL is a multi-disciplinary open access archive for the deposit and dissemination of scientific research documents, whether they are published or not. The documents may come from teaching and research institutions in France or abroad, or from public or private research centers.
L'archive ouverte pluridisciplinaire HAL, est destinée au dépôt et à la diffusion de documents scientifiques de niveau recherche, publiés ou non, émanant des établissements d'enseignement et de recherche français ou étrangers, des laboratoires publics ou privés. 


\section{Accepted Manuscript}

Title: Professionals' endorsement of behavioral finance: Does

it impact their perception of markets and themselves?

Authors: Lukas Menkhoff, Marina Nikiforow

PII: $\quad$ S0167-2681(09)00111-5

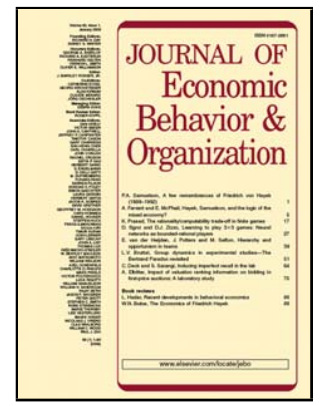

DOI: $\quad$ doi:10.1016/j.jebo.2009.04.004

Reference: $\quad$ JEBO 2370

To appear in:

Received date: $\quad 28-2-2007$

Revised date: $\quad 15-4-2009$

Accepted date: $\quad$ 15-4-2009

Please cite this article as: Menkhoff, L., Nikiforow, M., Professionals' endorsement of behavioral finance: Does it impact their perception of markets and themselves?, Journal of Economic Behavior and Organization (2008), doi:10.1016/j.jebo.2009.04.004

This is a PDF file of an unedited manuscript that has been accepted for publication. As a service to our customers we are providing this early version of the manuscript. The manuscript will undergo copyediting, typesetting, and review of the resulting proof before it is published in its final form. Please note that during the production process errors may be discovered which could affect the content, and all legal disclaimers that apply to the journal pertain. 


\title{
Professionals' endorsement of behavioral finance: Does it impact their perception of markets and themselves?
}

\author{
Lukas Menkhoff and Marina Nikiforow \\ Leibniz Universität Hannover, Germany
}

\begin{abstract}
This paper provides evidence on the hypothesis that many behavioral finance patterns are so deeply rooted in human behavior that they are difficult to overcome by learning. We test this on a target group which has undoubtedly very strong incentives to learn efficient behavior, i.e. fund managers. We split this group into endorsers and non-endorsers of behavioral finance. Endorsers do, indeed, view markets differently as they regard stronger influences from behavioral biases. However, when it comes to the perception of one's own behavior the endorsement of behavioral finance becomes almost meaningless, even though endorsers otherwise do adapt behavior towards their conviction.
\end{abstract}

JEL codes: G 10 (general financial markets), D 83 (learning, knowledge, belief) Keywords: behavioral finance, fund managers, biases

April 14, 2009

We thank all participating fund managers for their time and commitment; we thank participants at the German Economic Association Conference in Munich and at the European Financial Management Association Conference in Athens for their useful discussion. Moreover, we gratefully acknowledge the useful comments of two anonymous referees and research assistance by Torsten Brozynski.

menkhoff@gif.uni-hannover.de and nikiforow@gif.uni-hannover.de, both: Leibniz Universität Hannover, Königsworther Platz 1, D-30167 Hannover, Germany 


\section{Professionals' endorsement of behavioral finance: Does it impact their perception of markets and themselves?}

\section{Introduction}

The history of many anomalies in financial markets has shown that they disappear over time (Fama, 1998). This has raised the suspicion that markets may need time to recognize such anomalies - which largely motivate behavioral finance - but that they react consequently afterwards. According to this view one may assess behavioral finance being largely concerned with transitory phenomena. Others argue that many behavioral finance patterns are so deeply rooted in human behavior that they are difficult to overcome by learning (Alpert and Raiffa, 1982, Fischhoff, 1982b, Tversky and Kahneman, 1982, and more recently Hirshleifer, 2001). Obviously, these two views make contrary predictions on the persistence of behavioral phenomena although both camps agree that in the long run fundamentals drive prices. If rational learning is dominant then one could expect that insights into behavioral finance impact one's own behavior. If, however, learning mechanisms are weak in this respect the insights into behavioral finance will have a minor impact on one's own behavior. We provide a test of these competing views and find evidence in support of the latter hypothesis put forward by psychologists working in behavioral decision-making and more recently by behavioral economists. ${ }^{1}$

Our research aims for extending literature in psychology which has clearly revealed the "bias blind spot" (Pronin et al., 2002), i.e. the belief that one's own judgments are less susceptible to biases than the judgments of others. ${ }^{2}$ We extend this research by addressing an important objection that economists might voice against evidence based on student surveys: The probability that behavioral biases hold depends on how strong incentives are to learn and thus to overcome entrenched behavior. One can easily imagine circumstances where people adhere to behavioral patterns as forecast by behavioral finance just because their welfare is not at stake. It seems therefore advisable for an empirical examination of the hypothesis put forward by psychologists and behavioral economists to choose a target group that has un-

\footnotetext{
${ }^{1}$ Nowadays it is widely accepted that behavioral finance builds on two concepts, i.e. "investor psychology" and "limits to arbitrage" (see Shleifer and Summers, 1990, Barberis and Thaler, 2002).

2 This asymmetry arises from the stance of "naive realism" as well as from different strategies people apply to detect bias in own judgments versus the judgments of others (Pronin et al., 2004, see also Ehrlinger et al, 2005). Recent research in this line includes adding individual's self-image to the utility function (Johansson-Stenman and Martinsson, 2006).
} 
doubtedly strong incentives to learn. We have thus targeted professional fund managers. Their investment performance is on the one hand negatively affected by behavioral biases (see e.g. Shefrin and Statman, 1985, Coval and Shumway, 2005, Biais and Weber, 2007) and on the other permanently monitored and linked to high performance-related bonuses. Among these fund managers we differentiate between "endorsers" of behavioral finance and others, who we call "non-endorsers".

Endorsers of behavioral finance are those fund managers who believe that the approach of behavioral finance truly reflects decision behavior in fund management (and who know the key messages of behavioral finance well). In contrast to them are non-endorsers, i.e. fund managers who are not that much convinced about the relevance of behavioral finance. We have surveyed more than 100 fund managers in Germany and classify them according to their self-assessment into these two groups. We then analyze whether fund managers' endorsement of behavioral finance, i.e. being an "endorser", impacts their perception of markets and themselves: Do these groups respond in the same way to questionnaire items addressing, first, their perception of general fund managers' behavior and, second, their perception of their own behavior with respect to issues being raised by behavioral finance research?

We find a revealing split in responses: Whereas endorsers recognize significantly stronger behavioral finance effects in other fund managers' behavior than non-endorsers, the perception of their own behavior is largely unaffected by their insights. When endorsers are asked about their own behavior with respect to items being linked to behavioral finance, such as hindsight bias or disposition effect, they answer as non-endorsers do. However, there is one exception to this pattern: Endorsers show less miscalibration with respect to forecasting the interval of a stock index. As less miscalibration here also means more correct answers, this suggests that endorsers' conviction of behavioral finance may increase awareness for respective distortions and can improve decisions to some extent.

In a final exercise, we analyze whether endorsers' assessment of their own behavior may reflect the fact that behavioral finance does not influence their decisions in any respect. Therefore, we ask whether endorsers differ from non-endorsers regarding two further items of investment behavior, i.e. their preferred information sources and investment strategies. We find that both groups seem to differ clearly in their use of information sources although not to a statistically significant extent. The difference becomes significant, however, with respect to preferred investment strategies as endorsers rely more on momentum and contrarian strate- 
gies. We conclude that endorsers do not generally behave like non-endorsers, making the above found indifference between both groups with respect to their self-assessment more credible.

Thus, we come back to the hypothesis - proposed by psychologists and behavioral economists - that many behavioral patterns are difficult to overcome by learning. Our findings provide support for his view as insight into behavioral finance and thus into the behavior of others does not easily change one's own behavior. We regard it as an important and innovative aspect of our research that this result has been found among fund managers because this target group has strong incentives to improve behavior. In this respect we also find a partial justification for Fama's (1998) optimism into learning processes in that the endorsement of behavioral finance reduces miscalibration.

The remaining study is structured into four sections. Section 2 describes data of the questionnaire survey. The following sections present our analyses, starting with views on the market's behavior (Section 3), then views on one's own behavior (Section 4) and, finally, consequences on investment behavior (Section 5). Section 6 concludes.

\section{Data}

This study is based on a questionnaire survey that addressed all relevant fund management companies in Germany between August 15 and December 12, 2002 and yielded a useful and largely representative sample.

In total, out of the 59 relevant fund management companies 35 participated in the survey, with at least one appropriate questionnaire each. This resulted in a response rate of 59\% concerning participated fund management companies. ${ }^{3}$

To ensure the reliability of responses many intensive interviews with fund managers were conducted in advance of the survey. These interviews served to formulate questions in an appropriate manner. Furthermore, in later stages the questionnaire was used in a pre-test with several fund managers as a final check of its acceptance and appropriateness. Feedback indicates that the response is useful for our research purpose.

The descriptive statistics in Table 1 provide a picture of personal characteristics of the respondents in this survey. Accordingly, the mean of responding fund managers shows an age of about 35 years, has professional experience of ten years, is of male gender, earns a bo-

\footnotetext{
${ }^{3}$ The structure of this response is largely similar to the industry's structure. Our sample is representative in this sense (see Appendix 1).
} 
nus payment of $25 \%$, has a university degree, works rather in a non-governing position, practices active fund management and manages stocks rather than bonds. This data is consistent with the information from similar surveys in Germany such as Menkhoff (1998) or Arnswald (2001).

As basis for the formation of groups our questionnaire contains two useful statements on behavioral finance, i.e. endorsement and knowledge of behavioral finance. These statements are given in Table 2 as BF1 and BF2, both of which are assessed by 6 answering categories, ranging from "complete approval" (coded as 1) to "complete contradiction" (coded as 6). The main information we use from these statements is the degree of endorsement of behavioral finance as it is expressed in the response to BF1. Due to the distribution of answers (see the contingency table in Table 2) we define endorsers by comprising answering categories 1 and 2, whereas category 3 seems to characterize an intermediate stance in comparison to the sample. We complement this definition by information from BF2, i.e. we define that endorsers should also know the key messages of behavioral finance well (corresponding to answering categories 1 and 2 again). ${ }^{4} 3$ persons are not considered further in the analysis because they say to be convinced of behavioral finance (responding to BF1 with answering category 2) but have only limited knowledge about it (responding to BF2 with answering category 3 or 4$){ }^{5}$ Due to this definition based on answers to BF1 and BF2, the group of endorsers consists of 37 fund managers whereas the group of non-endorsers consists of 67 fund managers. Both groups are framed in the contingency table in Table 2.

As we aim for a comparison of endorsers with non-endorsers we use the descriptive items given in Table 1 in order to find out about differences in personal characteristics. Interestingly, the results in Table 3 don't disclose any such difference to be statistically significant or even close to significance. Thus, the endorsement to behavioral finance is not closely related to personal characteristics, such as being older or holding a better position etc. In order to test the robustness of this result we also run a binary probit regression where the varia-

\footnotetext{
4 Thus non-endorsers share the belief that behavioral finance does not reflect decision behavior in fund management quite well (statement BF1). However, two groups may be distinguished with respect to statement BF2, i.e. their knowledge about behavioral finance. Splitting responses into those non-endorsers who know behavioral finance well (categories 1 and 2) and the others (categories 3 and more) gives groups with 32 and 35 fund managers, respectively. We have thus repeated all analyses with three groups (endorsers and two kinds of nonendorsers) in order to see whether the behavioral finance knowledge of non-endorsers may be a driving force in understanding them. But results remain almost unchanged and are thus robust in this respect. Only the level of significance is sometimes negatively affected by smaller sample size.

5 There are another 7 fund managers who did not answer BF1 or BF2 in a useful way so that sample size is reduced from 114 to 107.
} 
ble "endorser vs. non-endorser" is "explained" by available personal characteristics. The last two columns in Table 3 show that there is also no significant relation in this multivariate approach. As endorsers of behavioral finance do not represent a particular sub-group among fund managers, we do not control for personal characteristics in our further research.

\section{Views on market's behavior}

We ask fund managers to express their view on the behavior of other fund managers, i.e. the market, with respect to effects stated by behavioral finance. We find consistently that endorsers observe these effects significantly stronger than non-endorsers.

In order to systemize the variety of human behavioral biases Hirshleifer (2001) follows earlier studies of psychologists (see e.g. Alpert and Raiffa, 1982, Fischhoff, 1982b) and assigns biases either to the process of judgment or to the process of decision-making. Analogically, we ask for fund managers' response to statements [1] and [2], that serve to detect the judgment biases house money effect and confirmatory bias, and their response to statements [3] to [5] that rather describe the decision biases reflection effect, home bias and herding. Table 4 presents the five statements we are analyzing and which we motivate in the following before going into results.

\subsection{Motivation}

Statement [1] in Table 4 addresses the house money effect caused by the mechanisms of heuristic simplification. Simplification becomes active because of the restraints in human information-processing capabilities due to which the complexity of the available basis of information is reduced by filtering out apparently irrelevant facts. By thus simplifying the information-input for decision-making perception of reality gets biased (Tversky and Kahneman, 1982). This can result in suboptimal decisions. In this context, house money effect describes the phenomenon that investors become less loss-averse and more likely to take risks when reinvesting recently made profits. The psychological explanation for this bias is that the perceived discomfort in case of a loss of the recently earned money is diminished by the fact that it was a gain before (Thaler and Johnson, 1990).

Statement [2] aims at the confirmatory bias which is attributed to the natural mechanism of self-deception. After a decision people tend to collect decision-confirming information thereby ignoring contrary evidence (Pronin, 2007). The confirmatory bias describes the ob- 
servation that people are prone to interpret even ambiguous information in favor of their earlier decision. These natural mechanisms of selective information perception interfere with rational learning, including the recognition of and learning from one's own mistakes. The motivation for the confirmatory bias is to preserve self-respect of the decider as well as to avoid regret and thus unpleasant feelings after decision-making (Festinger, 1957, Nickerson, 1998).

Statements [3] to [5] mention decision biases. Statement [3] serves to detect the reflection effect (Kahneman and Tversky, 1979), grasped here by risk seeking behavior in case of loss positions. The reflection effect describes the dependence of investors' risk attitude on the sign of the outcome, i.e. whether the outcomes are gains or losses. It is included in prospect theory by the s-shape of the value function: concave for gains indicating risk aversion and convex for losses indicating risk seeking. This bias partly contributes to explain the disposition effect. The preference to invest in near located markets, the home bias (statement [4]), is explained - in the behavioral finance approach - by the human preference for familiarity, which evokes the feeling of possessing more relevant information about the home market and thus being more competent to forecast (Kilka and Weber, 2000, Lütje and Menkhoff, 2007). The third decision bias addressed here with statement [5] is herding. It is understood as the phenomenon that fund managers may imitate the investment decision of others and thereby ignore their own valuable information (see Bikhchandani and Sharma, 2001).

\subsection{Results}

Regarding the results in Table 4 we detect significant differences between endorsers and non-endorsers concerning the intensity of perception of biases in their colleagues' behavior and thereby in the market. This finding applies to the two judgmental biases, i.e. house money effect and confirmatory bias, and to the three decisional biases as well, i.e. reflection effect, home bias and herding.

In all five cases endorsers recognize the biases significantly stronger than nonendorsers, even though the latter mostly concede the existence of these behavioral finance effects too. Taking for example the house money effect (statement [1]), endorsers approve this with a mean answer of 2.59 , whereas non-endorsers give a mean answer of 3.13 - indiffe- 
rence between approval and contradiction would occur at a value of 3.50. The difference between both groups is significant at the $5 \%$ level. $^{6}$

Remarkably, the perception of herding is by far strongest compared to other biases. All fund managers agree with a mean of 2.02 to statement [5]. Again, the difference between both groups is statistically significant as endorsers perceive herding among fund managers stronger than non-endorsers.

The results in Table 4 indicate that the major fraction of professional fund managers observes behavioral finance effects in their daily working environment. This may be interesting in itself but our focus lies on the difference between the two groups distinguished: Endorsers of behavioral finance perceive these effects significantly stronger than non-endorsers. We are not aware that this result has been shown before, although it may confirm expectations. Against the background of this finding the next section examines the impact from endorsement of behavioral finance on fund managers' self-assessment. Will endorsers be able to control and quell their psychologically motivated biases to rationalize their behavior in order to optimize investment performance?

\section{Views on one's own behavior}

The view on one's own behavior provides a stunning contrast to the view on the market (see Section 3): We do not find any significant differences between endorsers and nonendorsers in our sample, with one exception, i.e. the issue of miscalibration.

The answers to the following five items provide pretty consistent results about fund managers' self-assessment. Just as for the view on markets, we follow psychologists and behavioral economists and distinguish the self-assessment items in those of judgment and decision-making (see Table 5). The first part of this section shortly motivates these items, the second part gives empirical results.

\subsection{Motivation}

We refer to judgment biases with statement [6], question [7] and task [8] which serve to analyze the three facets of overconfidence as they have been discussed in the literature,

\footnotetext{
${ }^{6}$ As a referee notes, one may be concerned with the positive wording of statements in Table 4, as the observed tendency to agree with questions may reflect a bias in psychological measurement. However, this possibility is rather unlikely if one takes into account that these results do predict miscalibration and the choice of investment strategies in a meaningful way. Moreover, respondents rather deny the also positively worded statement 9 in Table 5 below. Finally, our study primarily focuses on differences between two groups.
} 
e.g. in Glaser and Weber (2007) and Menkhoff et al. (2006). Theory assumes that overconfidence often appears in situations with rare or ambiguous feedback (Lichtenstein et al., 1982, Hirshleifer, 2001). However, portfolio manager frequently get unmistakable feedback to their decisions and forecasts and they cannot establish themselves in the market with bad performance. In this context it seems plausible to expect that portfolio manger learn from their experience, thus being able to estimate the precision of their knowledge and abilities more adequate (Deaves et al., 2005). But, as indicated by the self-deception theory, the driving forces behind overconfidence may be stronger than rational learning. Many cognitive mechanisms distort an adequate self-assessment, thereby rather supporting overconfidence to keep selfesteem and respect of others after wrong decisions. Glaser et al. (2005) show in this respect that professional investors are even more overconfident than laymen in all the three interpretations of overconfidence.

The first dimension of overconfidence is the illusion of control (Langer, 1975) implying the following aspects: The belief of being able to control random variables, such as market trends, more than it is really possible, an unrealistic high estimation of one's own success probability as well as an exaggerated optimism concerning the future (Glaser and Weber, 2007). The psychological motivation for the illusion of control is the fact that people feel more comfortable in situations they can control. An aspect of this bias is the illusion of being able to explain events retrospectively which is also regarded as the origin of hindsight bias. Thus, we refer to overconfidence as illusion of control by statement [6]. Hindsight bias hinders an efficient information procession and derogates rational learning (Fischhoff, 1982a). Empirical studies show that despite the knowledge of its origins and effects, the hindsight bias cannot be easily reduced and that also professionals are subject to this bias (Fischhoff, 1982b, Biais and Weber, 2007).

One further facet of overconfidence is the unrealistically positive self-evaluation, the so called better-than-average-effect (Taylor and Brown, 1988) which we address by question [7]. Especially concerning desirable skills people tend to estimate themselves above average. A prominent example for the better-than-average self-estimation is the study of Svenson (1981), in which $82 \%$ of participating students rank themselves to $30 \%$ of the safest drivers. Obviously, biased perception concerning one's own skills is in high gear. From one's own experience only others are subject to cognitive deception and behavioral biases. Thereby suc- 
cesses are referred to one's own abilities whereas failures are ascribed to external circumstances (Pronin et al., 2002, Pronin, 2007).

Finally, overconfidence is often regarded as miscalibration which we test by using task [8]. Miscalibration is a systematic overestimation of the precision of one's own knowledge. In consequence, people underestimate the probability distribution of a random variable (Lichtenstein et al., 1982, Alpert and Raiffa, 1982). Experimental psychology adopted the method of confidence intervals to measure miscalibration. Investors signalize their miscalibration by stating too narrow confidence intervals for estimations of stock or stock index developments.

In the following we refer to two decision biases. When approaching disposition effect and home bias that we have already touched to assess the market (Section 3), we do not rely on the same items for self-assessment in order to prevent strategic answers by respondents.

Over the past 20 years, the most commonly mentioned behavioral finance explanation for the disposition effect is the prospect theory view with its core messages: loss aversion and reflection effect (Kahneman and Tversky, 1979, Weber and Camerer, 1998, Langer and Weber, 2005). Accordingly, loss aversion is responsible for risk seeking in case of losses and consequently for the tendency to holding loss positions too long. This behavior is attributed to the hope that loser assets will rise or even outperform the actual winners in the future. Contrary, due to risk aversion in the domain of gains the realization of a secure profit is preferred to further holding a "winning" asset. This leads to selling winners too soon. Thus, investors change their risk attitude depending on the type of an outcome, the above elucidated reflection effect. Interestingly, Shefrin and Statman (1985) point out that prospect theory cannot explain the disposition effect by its own and consequently use several additional psychological elements besides prospect theory, i.e. mental accounting, regret aversion and selfcontrol. ${ }^{7}$ Recent research provides further doubt on the direct one-to-one link between prospect theory and disposition effect. Prospect theory does not always explain the disposition effect or does even predict opposite behavior (Barberis and Xiong, 2006, Hens and Vlcek, 2006). We approach the disposition effect by statement [9], thereby in particular concerning risk aversion in the domain of gains. ${ }^{8}$

\footnotetext{
7 We thank a referee for making us aware of this point.

8 The exact formulation relies on Odean's (1998, p.1777) discussion of the disposition effect: "If the investor is faced with a liquidity demand, and has no new information about either stock, she is more likely to sell the stock that is up."
} 
Statement [10] refers to the home bias although with a different item than statement [4] from Table 4 above. We use the hypothetical question on international asset allocation here because fund managers are subject to restrictions of their clients who are not necessarily well informed about an optimal portfolio allocation or may be subject to regulation restricting international diversification. Thus, managed portfolios might differ from the ones preferred by the fund managers themselves. To avoid such a distortion, we ask fund managers for their personally preferred portfolio allocation, explicitly mentioning to ignore their funds' restrictions. According to the IAPM (International Asset Pricing Model) the optimal portfolio share of a country corresponds to the ratio of its market capitalization to world capitalization. German investors' portfolios should thus contain 4\% of German stocks and $8 \%$ of German bonds (Lütje and Menkhoff, 2007).

For all three biases - overconfidence, disposition effect and home bias - there is clear evidence that they reduce risk-adjusted investment performance. In a series of studies the dismal effect of overconfidence has been revealed by Odean (1999), Biais et al. (2005), Biais and Weber (2007). Also Barber and Odean $(2000,2001)$ ascribe detrimental high trading activity to overconfidence. ${ }^{9}$ Regarding the disposition effect, Odean (1998) discloses it as a source of suboptimal performance for individual investors. Shapira and Venezia (2001) find that both professionalism and experience diminish but do not eliminate the preference to realize profits too soon. A similar result is shown by Feng and Seasholes (2005): While sophistication and trading experience eliminate the reluctance to realize losses they only reduce but fail to eliminate the propensity to realize gains. Sluggish reaction due to the disposition effect may even generate stock price "underreaction" to corporate news (Frazzini, 2006). Accordingly, literature warns against the consequences of the disposition effect and proposes greater self-discipline as solution to reduce the costs of loss or regret aversion and relative unsuccessfulness (Coval and Shumway, 2005, Locke and Mann, 2005). Scherbina and Jin (2006) study the effect of replacements of mutual fund managers. They demonstrate that new fund managers sell the loser stocks they have inherited more readily, thus increasing future returns. Finally, there is evidence that international portfolio diversification may increase portfolio returns (depending of course on the benchmark country return) although emphasis is put on the advantage of international diversification due to imperfect return correlation between national markets (see Levy and Sarnat, 1970).

\footnotetext{
${ }^{9}$ See Hilton (2007) for a more detailed discussion of overconfidence.
} 


\subsection{Results}

We now turn to results which are presented in the main part of Table 5. Starting with the bias "illusion of control", is there any impact from being an endorser of behavioral finance on the degree of hindsight bias? By assessing statement [6] with a mean of 3.32 endorsers of behavioral finance find the majority of economic news slightly more surprising than non-endorsers (3.19). Illusion of control is not significantly lower for endorsers in this case although this tendency of information perception may seem desirable from the viewpoint of behavioral finance (as well as from the efficient market hypothesis). Thus, our result supports the persistence of the hindsight bias.

Question [7] sheds light on overconfidence as unrealistically positive self-evaluation. In absence of overconfidence it is to expect that fund managers evaluate their own performance compared to that of their colleagues on average with 3 , which is the coding for "equally good". The results in Table 5 show, however, that fund managers evaluate themselves by a mean of 2.34 , thus clearly signaling overconfidence. The difference between endorsers and non-endorsers in this respect is negligible.

Task [8] serves to analyze the relation of miscalibration and the endorsement of behavioral finance. In this case respondents had to estimate a $90 \%$ confidence interval for the quote of Germany's main stock index DAX in one month ahead. Interestingly, endorsers state a significantly wider interval than non-endorsers (means of 1165 and 769 points respectively). ${ }^{10}$ The share of correctly made forecasts is $66.7 \%$ in the group of endorsers and $47.2 \%$ in the group of non-endorsers. As the share of wrong estimations exceeds $10 \%$ we confirm miscalibration among professional fund managers in our sample (see e.g. Biais et al., 2005, Glaser et al., 2005) but show that miscalibration is significantly lower for endorsers of behavioral finance. This may be understood as successful learning by endorsers.

Turning to the disposition effect, i.e. statement [9], our groups do not differ in their assessment of the degree to be subject to the disposition effect themselves. They both rather deny it to hold too long on losing positions (means of 4.03 and 4.07 respectively). In contrast, they observe a related bias - the reflection effect- much clearer in the behavior of others (see Section 3, statement [3]).

\footnotetext{
${ }^{10}$ Excluding the extreme $10 \%$ answers from the distribution, leaving the inner $90 \%$, the Mann-Whitney U-test also shows a significant difference between the answers of the groups in the miscalibration task. The median in the group of endorsers is 760 points and 625 points in the group of non-endorsers.
} 
Finally, also the result for statement [10] does not differ between our two groups. Both groups equally strongly overweigh the home country in their portfolios. This finding is contrasted by results on statement [4] in Table 4, whereupon home bias is observed in fund management.

All this raises the question why overconfidence as miscalibration seems to be a bias that is easier to overcome than other behavioral patterns? Psychologists claim that people want to think well of themselves and generally succeed in doing so, which is particularly difficult to overcome by learning when asking for a direct comparison between self versus others (Pronin et al., 2002, 2004). Hence, e.g. overconfidence as better-than-average effect or the denial of the disposition effect in one's own behavior can be regarded as consequence of the wish to see oneself in a better light upon which the knowledge of these biases has no significant influence. The contrasting finding on the calibration task could thus be due to its formulation which does not directly ask to assess one's own skills as statements 6 and question 7 do. Therefore, this task might not activate the person-positivity bias, i.e. the affinity of individuals to assess themselves in far more positive terms than they assess most other people (Taylor and Brown, 1988). This could be the reason for why learning succeeds in the miscalibration task. Thus, if we regard the ambition to guard self-esteem as motivation to perform well in self-assessment, then in case of miscalibration endorsers of behavioral finance are, first, better informed how to attain a good result in this task, i.e. to forecast correctly, and, second, they are not (or less) hindered by cognitive self-esteem guarding mechanisms when answering this task. As a result, due to their greater awareness of miscalibration and the minor cognitive resistance to this task, endorsers state significantly wider (and thereby better) confidence intervals than non-endorsers.

In summary, we do not observe an impact of the endorsement of behavioral finance on one's own behavior. Rather, both groups - endorsers and non-endorsers - negate behavioral biases like the disposition effect in their own investment behavior. This creates a discrepancy between the view on the market and that on oneself, i.e. a clear disclosure of the bias blind spot. Thus, fund managers do not behave principally different from other people, despite their strong performance control and bonus incentives to rationalize behavior. ${ }^{11}$ Thus, ration-

\footnotetext{
11 Pronin et al. (2002) as well as Ehrlinger et al. (2005) reveal for "normal" people that even with knowledge of the relevant biases their perception in the behavior of others is always stronger than their recognition in one's own behavior. Furthermore, test persons fail to agree to this biased self-perception and hold on to judge their self-assessment as objective and accurate.
} 
al learning is difficult in case of self-perception (Ehrlinger et al., 2005) - here shown for fund managers.

\section{Consequence on investment behavior}

The purpose of this section is to analyze whether the endorsement to behavioral finance has any effect on practical investment behavior. As we find such effects, this serves as a credibility test of the bias blind spot - no impact on perception of own behavior - because endorsers obviously do behave differently in accordance with their conviction.

In this section investment behavior is grasped by two items, addressing information sources and investment strategies. It is known in this respect that fund managers primarily base their decision on fundamental information (e.g. Menkhoff, 1998, Arnswald, 2001). However, due to the increasing recognition of behavioral effects on price formation in financial markets (DeBondt and Thaler, 1985, Jegadeesh and Titman, 2001, Barberis and Thaler, 2003, Shiller, 2003) the importance of non-fundamental information, such as technical analysis and technical trading strategies (e.g. momentum trading) may be even growing (early evidence in Grinblatt et al., 1995, Keim and Madhavan, 1995). Because of their stronger perception of behavioral anomalies in financial markets we expect endorsers trying to profitably exploit the observed anomalies and thus to rely more on non-fundamental sources of information and investment strategies.

In detail, Table 6 gives task [11] with the four important sources of information as revealed by fund managers in ex-ante interviews. From the same set of interviews we derive most popular investment strategies as addressed by question [12] in Table 7.

Table 6 shows at first sight the superior role of fundamental facts as source of information for all fund managers. Compared to non-endorsers, the group of endorsers relatively stronger uses technical indicators (mean of 2.84 vs. 3.26), whereby it assesses colleagues (mean of 3.38) and other market participants (mean of 3.93) as relatively less relevant sources of information. Even if these differences are not significant, the tendency to reject the no-difference hypothesis is relatively obvious in some cases, e.g. regarding the p-value of the Mann-Whitney U-Test of 0.125 for technical indicators. Colleagues and other market participants can be interpreted as sources of external confirmation for own decisions (Arnswald, 2001). Their relatively minor importance for endorsers might result from the fact that the latter relatively stronger perceive the behavior of other market participants as biased (Table 4). 
Therewith, the quality of these sources of information is lower for endorsers. In this sense their endorsement of behavioral finance has a recognizable influence, although it is not statistically significant. ${ }^{12}$

Table 7 contains results about the use of the popular investment strategies in fund management. We see that the three main strategies as identified in interviews, i.e. buy-and-hold, momentum and contrarian trading, are of almost equal importance to our sample of fund managers. When we look at endorsers only, however, they prefer the technical trading strategies momentum and contrarian trading to a significantly higher degree than non-endorsers. This is consistent with their market assessment in Section 3 (Table 4) where they significantly stronger regard markets as being influenced by behavioral finance effects. In particular, the more intensive use of the momentum strategy seems plausible regarding the significantly stronger perception of herding in fund management (statement [5] in Table 4).

\section{Conclusion}

Recent empirical research in the field of behavioral finance has shown that professional investors are (just as well as private ones) subject to irrational, psychologically motivated biases in their investment decisions (e.g. Glaser et al., 2005, Haigh and List, 2005, Menkhoff et al., 2006). Even though professionalism may reduce biases to some degree it does not eliminate them entirely (Shapira and Venezia, 2001, 2006, Feng and Seasholes, 2005). This paper offers another perspective on the role of behavioral biases in finance by examining the impact from endorsement of behavioral finance on the perception of markets' and one's own behavior.

We provide evidence on this issue by examining survey data of more than 100 German fund managers. Distinguishing the respondents in two groups, endorsers and non-endorsers of behavioral finance, we test for differences in their answers with respect to perceived market-wide biases, self-assessment, information processing and investment strategies. Interestingly, there is no difference in personal characteristics between the two groups. Our findings show that the endorsement of behavioral finance has a significant impact on professionals' perception of markets, but that it hardly influences the view on one's own behavior. This

\footnotetext{
12 If we aggregate the four sources of information into a composite score (fundamental facts plus technical indicators minus colleagues minus other market participants) the difference between endorses and non-endorsers becomes significant ( $p$-value of 0.054): Compared to non-endorsers, endorsers assign relatively less importance to colleagues and other market participants than to fundamental facts and technical indicators.
} 
finding holds although endorsers do behave differently from non-endorsers in the expected direction with respect to preferred information sources and investment strategies.

So far our findings clearly support the hypothesis that many behavioral biases are difficult to overcome by learning, even though the fund managers analyzed here have very strong incentives to learn efficient behavior. However, results do not only feed pessimism about the capabilities of financial professionals. One indication of learning is the significantly lower degree of miscalibration shown by endorsers. Moreover, their stronger reliance on technical analysis and trading strategies may not conform to expectations derived from the efficient market hypothesis; however, this behavior seems consistent with their endorsement of behavioral finance.

The results of our study demonstrate the persistence of behavioral patterns even with knowledge of their existence and thus their dominance over rational learning (in this sample). The failure to recognize own biases prevents from striving to correct them (Fischhoff, 1982b, Pronin, 2007). The challenge for professional fund managers, in particular for those with insight in behavioral finance, consists therefore in a more critical assessment of own investment behavior in order to discipline and rationalize it. 


\section{References}

Alpert, M., Raiffa, H., 1982. A progress report on the training of probability assessors. In: Kahneman, D., Slovic, P., Tversky, A. (Eds.). Judgment under Uncertainty: Heuristics and Biases. Cambridge: Cambridge University Press, 294-305.

Arnswald, T., 2001. Investment behaviour of german equity fund managers: An exploratory analysis of survey data. Deutsche Bundesbank Discussion Paper 08/01, Frankfurt.

Barber, B.M., Odean, T., 2000. Trading is hazardous to your wealth: The common stock investment Performance of Individual Investors. Journal of Finance 55, 773-806.

Barber, B.M., Odean T., 2001. Boys will be boys: Gender, overconfidence, and common stock investment, Quarterly Journal of Economics 116, 261-292.

Barberis, N., Thaler R. 2003. A survey of behavioral finance. In: Constantinides, G.M., Harris, M., Stulz, R. (Eds.). Handbook of the Economics of Finance, Vol. 1B. Amsterdam: Elsevier, 1053-1123.

Barberis, N., Xiong, W., 2006. What drives the disposition effect? An analysis of a longstanding preference-based explanation. SSRN-Working Paper No. 12397.

Biais, B., Hilton, D., Mazurier, K., Pouget, S., 2005. Judgmental overconfidence, selfmonitoring and trading performance in an experimental financial market. Review of Economic Studies 72, 287-312.

Biais, B., Weber, M., 2007. Hindsight bias and investment performance. IDEI Working Paper No. 476.

Bikhchandani, S., Sharma, S., 2001. Herd behavior in financial markets: A review. IMF Staff Papers 47, 279-310.

Coval, J.D., Shumway, T., 2005. Do behavioral biases affect prices? Journal of Finance 60, $1-34$.

Deaves, R., Lüders, E., Schröder, M., 2005. The dynamics of overconfidence: Evidence from stock market forecasters. Center for European Economic Research (ZEW), ZEW Discussion Paper No. 05-83.

De Bondt, W.F.M., Thaler, R., 1985. Does the stock market overreact? Journal of Finance 40, 793-805.

Ehrlinger, J., Gilovich, T., Ross, L., 2005. Peering into the bias blind spot: People's assessments of bias in themselves and others. Personality and Social Psychology Bulletin 31, 680-692.

Fama, E.F., 1998. Market efficiency, long-term returns, and behavioral finance. Journal of Financial Economics 49, 283-306.

Feng, L., Seasholes, S., 2005. Do investor sophistication and trading experience eliminate behavioral biases in financial markets? Review of Finance 9, 305-351.

Festinger, L, 1957. A Theory of Cognitive Dissonance. Stanford, CA: Stanford University Press.

Fischhoff, B., 1982a. For those condemned to study the past: Heuristics and biases in hindsight. In: Kahneman, D., Slovic, P., Tversky, A. (Eds.). Judgment under Uncertainty: Heuristics and Biases. Cambridge: Cambridge University Press, 335-351. 
Fischhoff, B., 1982b. Debiasing. In: Kahneman, D., Slovic, P., Tversky, A. (Eds.). Judgment under Uncertainty: Heuristics and Biases. Cambridge: Cambridge University Press, 422-444.

Frazzini, A., 2006. The disposition effect and underreaction to news. Journal of Finance 61, 2017-2046.

Glaser, M., Langer, T., Weber, M., 2005. Overconfidence of professionals and lay men: Individual differences within and between tasks? SSRN-Working Paper No. 712583.

Glaser, M., Weber, M., 2007. Overconfidence and trading volume. The GENEVA Risk and Insurance Review 32, 1-36.

Grinblatt, M., Titman, S., Wermers, R., 1995. Momentum investment strategies, portfolio performance, and herding: A study of mutual fund behavior. American Economic Review $85,1088-1105$.

Haigh, M.S., List, J.A., 2005. Do professional traders exhibit myopic loss aversion? An experimental analysis. Journal of Finance 60, 523-534.

Hens, T., Vlcek, M., 2006. Does prospect theory explain the disposition effect? Working Paper No. 262, Institute for Empirical Research in Economics, University of Zurich.

Hilton, D., 2007. Overconfidence, trading and entrepreneurship: Cognitive and cultural processes in risk-taking. In: Topol, R., Walliser, B. (Eds.). Cognitive Economics: New Trends. Amsterdam: Elsevier, 225-235.

Hirshleifer, D., 2001. Investor psychology and asset pricing. Journal of Finance 56, 15331597.

Jegadeesh, N., Titman, S., 2001. Profitability of momentum strategies: An evaluation of alternative explanations. Journal of Finance 56, 699-720.

Johansson-Stenman, O., Martinsson, P., 2006. Honestly, why are you driving a BMW? Journal of Economic Behavior and Organization 60, 129-146.

Kahneman, D., Tversky, A., 1979. Prospect theory: An analysis of decision under risk. Econometrica 47, 263-292.

Keim, D.B., Madhavan, A., 1995. Anatomy of the trading process, empirical evidence on the behavior of institutional traders. Journal of Financial Economics 37, 371-398.

Kilka, M., Weber, M., 2000. Home bias in international stock return expectations. Journal of Psychology and Financial Markets 1, 176-192.

Langer, E.J., 1975. The illusion of control. Journal of Personality and Social Psychology 32, 311-328.

Langer, T., Weber, M., 2005. Myopic prospect theory vs. myopic loss aversion: How general is the phenomenon? Journal of Economic Behavior and Organization 56, 25-38.

Levy, H., Sarnat, M., 1970. International diversification of investment portfolios. The American Economic Review 60, 668-675.

Lichtenstein, S., Fischhoff, B., Phillips, L.D., 1982. Calibration of probabilities: The state of the art to 1980. In: Kahneman, D., Solvic, P., Tversky, A. (Eds.). Judgment under Uncertainty: Heuristics and Biases. Cambridge: Cambridge University Press, 306-334. 
Locke, P.R., Mann, S.C., 2005. Professional trader discipline and trade disposition. Journal of Financial Economics 76, 401-444.

Lütje, T., Menkhoff, L., 2007. What drives home bias? Evidence from fund managers' views. International Journal of Finance \& Economics 12, 21-35.

Menkhoff, L., 1998. The noise trading approach - questionnaire evidence from foreign exchange. Journal of International Money and Finance 17, 547-564.

Menkhoff, L., Schmidt, U., Brozynski, T., 2006. The impact of experience on risk taking, overconfidence, and herding of fund managers: Complementary survey evidence. European Economic Review 50, 1753-1766.

Nickerson, R.S., 1998. Confirmation bias: Ubiquitous phenomenon in many guises. Review of General Psychology 2, 175-220.

Odean, T., 1998. Are investors reluctant to realize their losses? Journal of Finance 53, 17751798.

Odean, T., 1999. Do investors trade too much? American Economic Review 89, 1279-1298.

Pronin, E., 2007. Perception and misperception of bias in human judgment. Trends in Cognitive Sciences 11, 37-43.

Pronin, E., Gilovich, T., Ross, L., 2004. Objectivity in the eye of the beholder: Divergent perception of bias in self versus others. Psychological Review 111, 781-799.

Pronin, E., Lin, D.Y., Ross, L., 2002. The bias blind spot: Perceptions of bias in self versus others. Personality and Social Psychology Bulletin 82, 369-381.

Scherbina, A., Jin, L., 2006. Inheriting Losers. SSRN Working Paper, EFA 2005 Moscow Meetings.

Shapira, Z., Venezia, I., 2001. Patterns of behavior of professionally managed and independent investors. Journal of Banking and Finance 25, 1573-1587.

Shapira, Z., Venezia, I., 2006. On timing and herding: Do professional investors behave differently than amateurs? Working Paper, European Financial Management Symposium 2006.

Shefrin, H., Statman, M., 1985. The disposition to sell winners too early and ride losers too long: Theory and evidence. Journal of Finance 40, 777-790.

Shiller, R.J., 2003. From efficient markets theory to behavioral finance. Journal of Economic Perspectives 17, 83-104.

Shleifer, A., Summers, L., 1990. The noise trader approach to finance. Journal of Economic Perspectives 4, 19-33.

Svenson, O., 1981. Are we all less risky and more skilful than our fellow drivers?. Acta Psychologica 47, 143-148.

Taylor, S.S., Brown, J.B., 1988. Illusion and well-being: A social psychology perspective on mental health. Psychological Bulletin 103, 193-210.

Thaler, R.H., Johnson, E.J., 1990. Gambling with the house money and trying to break even: The effects of prior outcomes on risky choice. Management Science 36, 643-660. 
Tversky, A., Kahneman, D., 1982. Judgment under uncertainty: Heuristics and biases. In: Kahneman, D., Slovic, P., Tversky, A. (Eds.). Judgment under Uncertainty: Heuristics and Biases. Cambridge: Cambridge University Press, 3-20.

Weber, M., Camerer, C.F., 1998. The disposition effect in securities trading: An experimental analysis. Journal of Economic Behavior and Organization 33, 167-184. 
TABLE 1. Descriptive statistics of respondents

\begin{tabular}{llllc}
\hline Item asked & \multicolumn{2}{l}{ Responses (in per cent) } & $\begin{array}{c}\text { Number of } \\
\text { responses }\end{array}$ \\
\hline Age (in years) & $<35: 50.9$ & $35-45: 46.5$ & $>45: 2.6$ & 114 \\
Professional experience (in years) & $<5: 22.3$ & $5-15: 59.8$ & $>15: 17.9$ & 112 \\
Gender & Male: 92.1 & Female: 7.9 & & 114 \\
Share of bonus payment & Mean: 25.8 & Std. dev.: 14.5 & 85 \\
University degree & Yes: 84.8 & No: 15.2 & 112 \\
Governing position & Yes: 36.9 & No: 63.1 & 103 \\
Kind of fund management (primarily) & Active: 93.7 & Passive: 6.3 & 111 \\
Kind of securities managed* & Stocks: 66.5 & Bonds: 33.5 & & 115 \\
\hline
\end{tabular}

Note: $* 4.2 \%$ of the respondents managed stocks and bonds to the same degree. These respondents were added with half weight to stocks as well as bonds, so that the sum adds up to $100 \%$.

\section{TABLE 2. Endorsers and non-endorsers}

[BF1] Statement: "The research findings in behavioral finance reflect decision behavior in fund management".

[BF2] Statement: "I've already concerned myself with behavioral finance, the key messages are well known to me".

\begin{tabular}{|c|c|c|c|c|c|c|c|c|}
\hline & & \multicolumn{6}{|c|}{ Distribution of responses (frequencies) } & \\
\hline & & \multicolumn{6}{|c|}{$\begin{array}{c}\text { BF1: Research findings reflect } \\
\text { decision behavior in fund management } \\
\text { complete approval } \quad \text { complete contradiction }\end{array}$} & \\
\hline \multirow{8}{*}{$\begin{array}{l}\text { BF2: } \\
\text { Key messages of be- } \\
\text { havioral finance are } \\
\text { well known to } \\
\text { respondent }\end{array}$} & & 1 & 2 & 3 & 4 & 5 & 6 & $\sum$ \\
\hline & 1 & 5 & 20 & 7 & 2 & 0 & - & 34 \\
\hline & 2 & 1 & 11 & 17 & 4 & 2 & - & 35 \\
\hline & 3 & 0 & 2 & 9 & 5 & 5 & - & 21 \\
\hline & 4 & 0 & 1 & 4 & 5 & 4 & - & 14 \\
\hline & 5 & 0 & 0 & 2 & 0 & 1 & - & 3 \\
\hline & 6 & - & - & - & - & - & - & - \\
\hline & $\sum$ & 6 & 34 & 39 & 16 & 12 & - & 107 \\
\hline
\end{tabular}


TABLE 3. Characteristics of endorsers and non-endorsers

\begin{tabular}{|c|c|c|c|c|c|c|c|}
\hline \multirow{3}{*}{$\begin{array}{l}\begin{array}{l}\text { Statements } \\
\text { encoding in [ ] }\end{array} \\
\begin{array}{l}\text { Age in years } \\
<35[1], 35-45[3\end{array}\end{array}$} & \multirow{3}{*}{$\begin{array}{c}\begin{array}{c}\text { Response } \\
\text { category } \\
\text { (a) }\end{array} \\
\begin{array}{c}\text { Mean } \\
\text { N }\end{array}\end{array}$} & \multicolumn{3}{|c|}{ Responses } & \multirow{3}{*}{$\begin{array}{c}\mathrm{H}_{0}: \text { No } \\
\text { difference } \\
-0.031 \\
(0.975)\end{array}$} & \multirow{2}{*}{\multicolumn{2}{|c|}{$\begin{array}{l}\text { Binary probit } \\
\text { regressions } \\
(\mathrm{c})\end{array}$}} \\
\hline & & \multirow{2}{*}{$\begin{array}{c}\begin{array}{c}\text { All fund } \\
\text { managers }\end{array} \\
2.04 \\
114\end{array}$} & \multirow{2}{*}{$\begin{array}{c}\text { Endorsers } \\
2.08 \\
37\end{array}$} & \multirow{2}{*}{$\begin{array}{c}\begin{array}{c}\text { Non- } \\
\text { endorsers }\end{array} \\
\begin{array}{c}2.09 \\
66\end{array}\end{array}$} & & & \\
\hline & & & & & & $\begin{array}{l}-0.208 \\
(0281)\end{array}$ & $\begin{array}{l}-0.151 \\
(0.349)\end{array}$ \\
\hline Professional experience in & $\begin{array}{c}\text { Mean } \\
\mathrm{N}\end{array}$ & 2.89 & $\begin{array}{c}3.00 \\
34\end{array}$ & $\begin{array}{c}2.82 \\
67\end{array}$ & $\begin{array}{l}-0.725 \\
(0.468)\end{array}$ & $\begin{array}{c}0.260 \\
(0.158)\end{array}$ & $\begin{array}{r}0.158 \\
(0285)\end{array}$ \\
\hline Gender & Mean & 1.08 & 1.05 & 1.08 & -0.437 & 1.019 & 0.150 \\
\hline male [1], female [2] & $\mathrm{N}$ & 115 & 37 & 65 & $(0.662)$ & $(0.209)$ & $(0.802)$ \\
\hline $\begin{array}{l}\text { Share variable } \\
\text { compensation in \% }\end{array}$ & $\begin{array}{l}\text { Mean } \\
\mathrm{N}\end{array}$ & $\begin{array}{c}25.78 \\
85\end{array}$ & $\begin{array}{c}28.35 \\
30\end{array}$ & $\begin{array}{c}25.53 \\
49\end{array}$ & $\begin{array}{l}-0.728 \\
(0.467)\end{array}$ & $\begin{array}{c}7.62 * 10^{-5} \\
(0.995)\end{array}$ & - \\
\hline $\begin{array}{l}\text { University degree } \\
\text { yes [1], no [2] }\end{array}$ & $\begin{array}{c}\text { Mean } \\
\mathrm{N}\end{array}$ & $\begin{array}{l}1.15 \\
112\end{array}$ & $\begin{array}{l}1.17 \\
36\end{array}$ & $\begin{array}{c}1.12 \\
65\end{array}$ & $\begin{array}{l}-0.604 \\
(0.546)\end{array}$ & $\begin{array}{l}0.211 \\
(0.667)\end{array}$ & $\begin{array}{r}0.213 \\
(0.593)\end{array}$ \\
\hline $\begin{array}{l}\text { Governing position } \\
\text { yes [1], no [2] }\end{array}$ & $\begin{array}{c}\text { Mean } \\
\mathrm{N}\end{array}$ & $\begin{array}{l}1.62 \\
105\end{array}$ & $\begin{array}{c}1.63 \\
30\end{array}$ & $\begin{array}{c}1.63 \\
64\end{array}$ & $\begin{array}{l}-0.077 \\
(0.938)\end{array}$ & $\begin{array}{c}0.130 \\
(0.745)\end{array}$ & - \\
\hline $\begin{array}{l}\text { Kind of fund management } \\
\text { (primarily) active [1], passive [2] }\end{array}$ & $\begin{array}{c}\text { Mean } \\
\mathrm{N}\end{array}$ & $\begin{array}{l}1.06 \\
110\end{array}$ & $\begin{array}{c}1.03 \\
35\end{array}$ & $\begin{array}{c}1.06 \\
65\end{array}$ & $\begin{array}{l}-0.718 \\
(0.473)\end{array}$ & $\begin{array}{l}-0.891 \\
(0.305)\end{array}$ & $\begin{array}{l}-0.603 \\
(0.409)\end{array}$ \\
\hline $\begin{array}{l}\text { Kind of securities managed } \\
\text { stocks [1], bonds [2] }\end{array}$ & $\begin{array}{c}\text { Mean } \\
\mathrm{N}\end{array}$ & $\begin{array}{l}1.34 \\
114\end{array}$ & $\begin{array}{c}1.30 \\
35\end{array}$ & $\begin{array}{l}1.40 \\
67\end{array}$ & $\begin{array}{l}-0.986 \\
(0.324)\end{array}$ & $\begin{array}{l}-0.210 \\
(0.556)\end{array}$ & $\begin{array}{l}-0.233 \\
(0.434)\end{array}$ \\
\hline $\begin{array}{l}\mathrm{R}^{2} \\
{[\mathrm{~N}]}\end{array}$ & & & & & & $\begin{array}{c}0.062 \\
67\end{array}$ & $\begin{array}{c}0.024 \\
93\end{array}$ \\
\hline
\end{tabular}

(a) Responses in respective answering categories with analogical encoding in the first column.

(b) $\mathrm{H}_{0}$ states that there is no difference between the groups of endorsers and non-endorsers. The figures given are the z-value of the Mann-Whitney U-test and the p-value in parenthesis.

(c) The table gives the coefficient of the binary probit regression and the p-value in parenthesis.

Stars refer to level of significance: ${ }^{*} 10 \%,{ }^{* *} 5 \%,{ }^{* * *} 1 \%$. 


\section{TABLE 4. Assessment of other fund managers' behavior}

[1] Statement: "After several profitable investments fund managers tend to take on additional positions".

[2] Statement: "My colleagues pay particular attention to confirmatory news/information after having made an investment decision".

[3] Statement: "In case of loss positions other fund managers tend to increase their willingness to take risks".

[4] Statement: "Fund managers prefer to invest in near located markets".

[5] Statement: "Also fund managers exhibit herding behavior".

\begin{tabular}{|c|c|c|c|c|c|c|}
\hline \multicolumn{2}{|c|}{ Statements } & $\begin{array}{l}\text { Response } \\
\text { category } \\
\text { (a) }\end{array}$ & \multicolumn{3}{|c|}{ Responses } & \multirow{2}{*}{$\begin{array}{c}\mathrm{H}_{0}: \\
\text { No difference } \\
-2.107^{* *}\end{array}$} \\
\hline [1] & HOUSE MONEY EFFECT & $\begin{array}{c}\text { Mean } \\
\mathrm{N}\end{array}$ & $\begin{array}{c}\text { All fund } \\
\text { managers } \\
2.92 \\
115\end{array}$ & $\begin{array}{c}\text { Endorsers } \\
2.59\end{array}$ & $\begin{array}{c}\begin{array}{c}\text { Non- } \\
\text { endorsers }\end{array} \\
3.13 \\
67\end{array}$ & \\
\hline [2] & CONFIRMATORY BIAS & $\begin{array}{c}\text { Mean } \\
\mathrm{N}\end{array}$ & $\begin{array}{r}2.66 \\
115\end{array}$ & $\begin{array}{c}2.35 \\
37\end{array}$ & $\begin{array}{c}2.91 \\
66\end{array}$ & $\begin{array}{c}-2.483^{* *} \\
(0.013)\end{array}$ \\
\hline [3] & REFLECTION EFFECT & $\begin{array}{c}\text { Mean } \\
\mathrm{N}\end{array}$ & $\begin{array}{l}3.44 \\
114\end{array}$ & $\begin{array}{c}3.00 \\
37\end{array}$ & $\begin{array}{c}3.71 \\
65\end{array}$ & $\begin{array}{c}-2.639^{* * *} \\
(0.008)\end{array}$ \\
\hline$[4]$ & HOME BIAS & $\begin{array}{c}\text { Mean } \\
\mathrm{N}\end{array}$ & $\begin{array}{r}3.34 \\
116\end{array}$ & $\begin{array}{c}3.03 \\
37\end{array}$ & $\begin{array}{c}3.54 \\
67\end{array}$ & $\begin{array}{l}-1.745^{*} \\
(0.081)\end{array}$ \\
\hline & HERDING & $\begin{array}{l}\text { Mean } \\
\mathrm{N}\end{array}$ & $\begin{array}{l}2.02 \\
116 \\
\end{array}$ & $\begin{array}{c}1.81 \\
37 \\
\end{array}$ & $\begin{array}{c}2.19 \\
67 \\
\end{array}$ & $\begin{array}{l}-1.841^{*} \\
(0.066) \\
\end{array}$ \\
\hline
\end{tabular}

(a) There are 6 answering categories, ranging from "complete approval" (coded as 1) to "complete contradiction" (coded as 6). Thus, a mean of 3.5 or less indicates rather approval to the statement. $\mathrm{N}$ is the number of responses.

(b) $\mathrm{H}_{0}$ states that there is no difference between the groups of endorsers and non-endorsers. The figures given are the z-value of the Mann-Whitney U-test and the p-value in parenthesis.

Stars refer to level of significance: ${ }^{*} 10 \%,{ }^{* *} 5 \%,{ }^{* * *} 1 \%$. 


\section{TABLE 5. Assessment of one's own behavior}

[6] Statement: "The majority of economic news is not surprising for me".

[7] Question: "How do you evaluate your own performance compared to other asset managers?"

[8] Task: "Give an estimation of the DAX in one month. Determine a lower und an upper bound such that the quote of the DAX in one month from now will be inside the resulting interval with a probability of $90 \% \%$.

[9] Statement: "I prefer to take profits when I am confronted with unexpected liquidity demands".

[10] Task: "Please, allocate an amount of 10 million $€$ to the following markets so that the shares sum up to $100 \%$ (thereby ignore your funds' restrictions)". Germany, Europe (without Germany), USA and Canada, Asia, Emerging Markets.

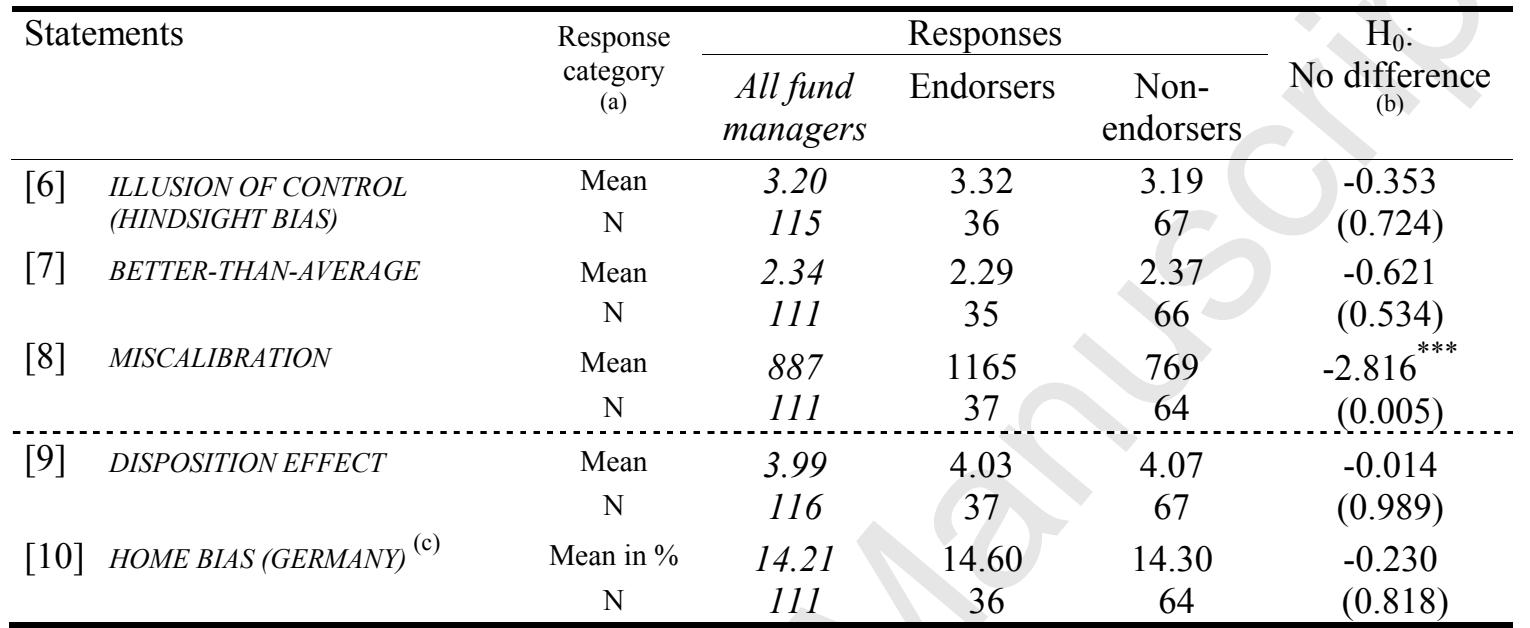

(a) There are 6 answering categories, ranging from "complete approval" (coded as 1) to "complete contradiction" (coded as 6). Thus, a mean of 3.5 or less indicates rather approval to the statement.

Statement 7: 5 answering categories: much better (coded as 1), slightly better (coded as 2), equally good (coded as 3), slightly worse (coded as 4), much worse (coded as 5). $\mathrm{N}$ is the number of responses.

(b) $\mathrm{H}_{0}$ states that there is no difference between the groups of endorsers and non-endorsers. The figures given are the $\mathrm{z}$-value of the Mann-Whitney U-test and the p-value in parenthesis.

(c) Concerning the weighting of other countries there are also no significant differences between the groups.

Note: All managers' mean answer for statements [9] and [10] lies not between the means of the comparison groups due to adjustment of the group "endorsers" by 3 answers (Table 2.).

Stars refer to level of significance: ${ }^{*} 10 \%,{ }^{* *} 5 \%,{ }^{* * *} 1 \%$. 


\section{TABLE 6. Assessment of information sources}

[11] Task: "Please, assess the importance of the following sources of information for you". Answering categories: "Fundamental facts about the company / market", "Technical indicators", "Colleagues from the own company", "Other market participants, not from the own company".

\begin{tabular}{|c|c|c|c|c|c|}
\hline \multirow[t]{2}{*}{ Sources of information } & \multirow{2}{*}{$\begin{array}{l}\text { Response } \\
\text { category } \\
\text { (a) }\end{array}$} & \multicolumn{3}{|c|}{ Responses } & \multirow{2}{*}{$\begin{array}{c}\mathrm{H}_{0}: \\
\text { No difference } \\
\text { (b) }\end{array}$} \\
\hline & & $\begin{array}{l}\text { All fund } \\
\text { managers }\end{array}$ & Endorsers & $\begin{array}{c}\text { Non- } \\
\text { endorsers }\end{array}$ & \\
\hline \multirow[t]{2}{*}{ Fundamental facts } & Mean & 1.82 & 1.86 & 1.87 & -0.588 \\
\hline & $\mathrm{N}$ & 115 & 37 & 67 & $(0.557)$ \\
\hline \multirow[t]{2}{*}{ Technical indicators } & Mean & 3.02 & 2.84 & 3.26 & -1.533 \\
\hline & $\mathrm{N}$ & 114 & 37 & 66 & $(0.125)$ \\
\hline \multirow[t]{2}{*}{ Colleagues } & Mean & 3.17 & 3.38 & 3.07 & -1.147 \\
\hline & $\mathrm{N}$ & 115 & 37 & 67 & $(0.251)$ \\
\hline \multirow[t]{2}{*}{ Other market participants } & Mean & 3.73 & 3.93 & 3.61 & -1.258 \\
\hline & $\mathrm{N}$ & 115 & 37 & 67 & $(0.208)$ \\
\hline
\end{tabular}

(a) There are 6 answering categories, ranging from "highest relevance" (coded as 1) to "no relevance" (coded as 6). $\mathrm{N}$ is the number of responses.

(b) $\mathrm{H}_{0}$ states that there is no difference between the groups of endorsers and non-endorsers. The figures given are the z-value of the Mann-Whitney U-test and the p-value in parenthesis.

Stars refer to level of significance: ${ }^{*} 10 \%,{ }^{* *} 5 \%,{ }^{* * *} 1 \%$.

\section{TABLE 7. Assessment of investment strategies}

[12] Question: "How intensive do you use several strategies? Please, allocate 100\%." Answering categories: “_ \% Momentum strategy”, "_ \% Buy-and-Hold strategy”, "_ \% Contrarian strategy (Value strategy)", “_ \% Others".

\begin{tabular}{|c|c|c|c|c|c|}
\hline \multirow[t]{2}{*}{ Investment strategies } & \multirow{2}{*}{$\begin{array}{l}\text { Response } \\
\text { category } \\
\text { (a) }\end{array}$} & \multicolumn{3}{|c|}{ Responses } & \multirow{2}{*}{$\begin{array}{c}\mathrm{H}_{0}: \\
\text { No difference } \\
(\mathrm{b})\end{array}$} \\
\hline & & $\begin{array}{l}\text { All fund } \\
\text { managers }\end{array}$ & Endorsers & $\begin{array}{c}\text { Non- } \\
\text { endorsers }\end{array}$ & \\
\hline Momentum & $\begin{array}{c}\text { Mean in \% } \\
\mathrm{N}\end{array}$ & $\begin{array}{c}26.27 \\
108\end{array}$ & $\begin{array}{c}29.49 \\
36\end{array}$ & $\begin{array}{c}23.92 \\
62\end{array}$ & $\begin{array}{l}-2.033^{* *} \\
(0.042)\end{array}$ \\
\hline Contrarian & $\begin{array}{c}\text { Mean in \% } \\
\mathrm{N}\end{array}$ & $\begin{array}{c}29.31 \\
108\end{array}$ & $\begin{array}{c}34.28 \\
36\end{array}$ & $\begin{array}{c}26.96 \\
62\end{array}$ & $\begin{array}{l}-2.395^{* *} \\
(0.017)\end{array}$ \\
\hline Buy-and-Hold $^{(\mathrm{c})}$ & $\begin{array}{c}\text { Mean in \% } \\
\mathrm{N}\end{array}$ & $\begin{array}{c}30.73 \\
108\end{array}$ & $\begin{array}{c}23.54 \\
36\end{array}$ & $\begin{array}{c}32.96 \\
62\end{array}$ & $\begin{array}{l}-1.159 \\
(0.243)\end{array}$ \\
\hline Others & $\begin{array}{c}\text { Mean in \% } \\
\mathrm{N}\end{array}$ & $\begin{array}{c}13.69 \\
108\end{array}$ & $\begin{array}{c}12.69 \\
36\end{array}$ & $\begin{array}{c}16.16 \\
62\end{array}$ & $\begin{array}{l}-0.113 \\
(0.910)\end{array}$ \\
\hline
\end{tabular}

(a) $\mathrm{N}$ is the number of responses.

(b) $\mathrm{H}_{0}$ states that there is no difference between the groups of endorsers and non-endorsers. The figures given are the z-value of the Mann-Whitney U-test and the p-value in parenthesis.

(c) The standard deviation for the buy-and-hold strategy is much larger than that for momentum and contrarian strategies, which explains the insignificant difference of groups' answers in this case.

Stars refer to level of significance: ${ }^{*} 10 \%,{ }^{* *} 5 \%,{ }^{* * *} 1 \%$. 


\section{APPENDIX 1. Comparison of the sample with the industry's structure}

Structure of the German asset management industry:

Structure of data sample:

- by assets under management

- by assets under management

$$
\mathrm{H}_{0} \text { : No difference }{ }^{(b)}
$$

$-0.325(0.745)$

$\begin{array}{cccc} & & \text { - by company size } & \\ & \text { Small player } & \text { Medium player } & \text { Big player } \\ \text { - by company size }^{2)} & {[12]} & {[24]} & {[8]} \\ & 5 & 13 & 8 \\ & & \mathrm{H}_{0}: \text { no difference }^{(\mathrm{c})} & \\ & & 2.981(0.225) & \end{array}$

Participation in the survey:

Pearson correlation coefficient with company size (by asset under management, $\mathrm{p}$-value in parentheses)

- by number of questionnaires per company

$0.472^{* * *}(0.001)$

The market data is based on the annual report of the German investment and asset management association (BVI) as of 2002.

(a) The table gives the z-value of the Mann-Whitney U-test with the p-value in parentheses.

(b) Here we focus on the company size of BVI member firms (ex those managing special funds only). The groups are clustered as follows: small players (mutual fund market share $<0.1 \%$ ), medium players (mutual fund market share $<=2.5 \%$ ), and big players (mutual fund market share $>2.5 \%$ ) with numbers given in squared bracket.

(c) The table gives the test statistic of the chi-square test with the p-value in parentheses.

Stars refer to level of significance: ${ }^{*} 10 \%,{ }^{* *} 5 \%,{ }^{* * *} 1 \%$. 